\title{
Muslim Punks and State Sharica
}

\author{
Reza Idria
}

I came to know Dema when he was hiding at Komunitas Tikar Pandan, an NGO for cultural programs in Banda Aceh. ${ }^{1}$ It was on 10 December 2011, and Dema had arrived there shortly after midnight. I still remember that he rushed to enter our building when we had just finished our weekly 'movie night' screening program. At the moment, he just told us very briefly that the Wilayatul Hisbah (the 'Shari'a police,' wH) were hunting punks outside our office and he wanted to be away from them. ${ }^{2}$ No one at Komunitas Tikar Pandan knew him before. But, as the news spread quickly about the punk raid which had just happened that evening, it was not difficult for us to identify Dema due to his physical appearance, with spiked hair and chain-filled clothes, as someone from the hunted group.

We had heard the news about the punk crackdown through social media just before Dema entered our office. The information spread quickly. 65 youths were detained by a combination of civil police and the wH after being accused of falsifying their music concert permit. Dema eventually told us more about the concert he and his friends had organized, how all seemed to be going well with the event until the Banda Aceh authorities came to arrest them. The concert was entitled "Aceh for the Punk: A Music Parade and Fundraiser for Orphanages." It took place at the Aceh Cultural Centre (Taman Budaya Aceh) and featured punk bands from various parts of Indonesia including Jakarta, Bekasi, Lampung, Jambi, Pekanbaru and Batam. After three bands had performed on stage, officers of the police force and the $\mathrm{WH}$, accompanied by the Deputy Mayor of Banda Aceh, stopped the concert. The officers stormed the venue, rounding up those who were dressed in punk style, mohawk hair,

1 I offer my sincere thanks to Michael Feener, David Kloos and Annemarie Samuels for their careful readings and suggestions that have sharpened and enriched my present work. I also want to thank Moch Nur Ichwan for helpful conversations at the early stage of this research. Part of this research was made possible by financial support from the Islam Research Programme Jakarta, a collaboration of the Netherlands Ministry of Foreign Affairs and Leiden University.

2 On the wH, see Feener (2013a, 219-249), as well as the chapter by Jan Michiel and Benjamin Otto in this volume. 
tattoos, and chains. They were arrested and brought to the local police station. Many of them were badly beaten. Dema was fortunate and managed to escape from the sweeping. He fled on his motorbike and sought a place to hide from the police. I asked him why he came to Komunitas Tikar Pandan, rather than some other place. He said it was just unintentional. But he did not deny that he was familiar with our cultural-based organization activities and knew already where it was located.

Tikar Pandan's headquarter is housed in a sprawling, decrepit mansion set in a semi-rural area with fences wrought of living trees. It has been popular as a cultural centre in Banda Aceh since 2003. Formed under the conditions of military emergency, Komunitas Tikar Pandan was founded by a group of local artists and student activists, including myself, in order to create a space for creative activities. Framed in terms of a cultural movement and cultural critique, Komunitas Tikar Pandan had chosen the safest way to launch protests against the political violence of Aceh during the conflict. Komunitas Tikar Pandan was also one of the main critics of the BRR (the Rehabilitation and Reconstruction Agency) during the post-tsunami rebuilding program. ${ }^{3}$ In 2007, Tikar Pandan further evolved to become the Liga Kebudayaan or 'Cultural League' with several divisions working and managing independently but remaining under one "umbrella" called Liga Kebudayaan Komunitas Tikar Pandan or Komunitas Tikar Pandan Cultural League. Those divisions include Sekolah Menulis Dokarim (The Dokarim Writing School), the Dokarim bookstore, TV Eng Ong \& Institute Tukang Cerita (Institute of Traditional Story Telling), Metamorfosa Institute, Jurnal Kebudayaan Gelombang Baru (The New Wave Journal) and Tikar Pandan Public Library. In 2011, the Liga Kebudayaan Komunitas Tikar Pandan also launched a new division called Museum HAM Aceh or the Aceh Human Rights Museum. ${ }^{4}$ Its facilities include a multi-purpose space which has been used as a museum and as a library dedicated to the memory of the conflict. Komunitas Tikar Pandan also uses this space to run film series, book readings, lectures and discussions concerning violence and human rights issues. ${ }^{5}$

3 For further discussion of Komunitas Tikar Pandan, see Grayman (2012). Komunitas Tikar Pandan's engagement in advocating the rights of Punk and other minority groups in Aceh has briefly been sketched in my "Cultural Resistance against Shariatism in Aceh" (2013), and recently in Hendrie (2014). The Komunitas Tikar Pandan website is www.tikarpandan.org.

4 For more on the Aceh Human Rights Museum program, see http://www.museumhamaceh .org/.

5 This project has been organized by Komunitas Tikar Pandan in cooperation with several human rights-based organizations, such as LBн Banda Aceh (Legal Aid Agency of Banda Aceh), KontraS Aceh (Commission for "the Disappeared" and Victims of Violence) and Koalisi NGO-HAM Aceh (Coalition of Human Rights NG Os Aceh). 
Following the 2011 punk concert incident, a number of local civil society organizations and NGOS offered assistance to those who suffered from the police crackdown. The lawyers from Banda Aceh's Legal Aid Institution (LBH) offered to provide free legal aid to release the arrested punks. When Dema arrived at the Tikar Pandan house, he asked for advice on the situation. The LBH staff recommended that we provide a little space for Dema and his fellow punks to stay. In the meantime, they would provide legal aid. Tikar Pandan agreed to allow Dema to stay in its office's garage. Some of his fellow punks joined him there later on, but none of them stayed as long as Dema.

During the course of Dema's stay at Tikar Pandan, I sought out opportunities to get to know him better. This was not always easy. For example, I found that there was almost no chance to talk to him before the sun went down. I was not sure whether he was afraid of something or someone, or whether it was just a habit. Dema's daily schedule was the reverse of ours. As far as I could tell, he always went to sleep in the morning and woke up in the evening. He started his 'day' with leftovers found in the kitchen. He ate very little. Sometimes he asked the Tikar Pandan members for coffee and cigarettes but he never complained if people were unresponsive to his begging. Nights were spent surfing the internet, modifying his punk outfit and writing songs for his band. ${ }^{6}$ Whenever I spent time in the Tikar Pandan office at night, he asked me to look at some song lyrics he was writing during his stay in our office. Unsurprisingly, these were all about protest and his critique of 'the mainstream.' I thought this would be the first time in my life to deal with a person who embodied such calmness. At times, Dema would also open up, and he easily spent hours talking to people he could trust.

Dema was born and raised in Banda Aceh. He repeatedly told me-with a smile on his face-that his ancestors came from the Arab peninsula. In Indonesia, descendants of Arabs are often associated with the family of the Prophet Muhammad and his companions. I sometimes called him 'Sayyid' or 'Habib,' as many people with Arabic ancestors are called. He told me his family did not use that laqab (honorific). Sometimes I joked that the Prophet would not be happy if he knew that one of his descendants has become a punker. Dema laughed at this, but then argued that there had been a lot of punks avant la lettre since the early days of Islam, even during the Prophet's lifetime.

6 In our discussions about punk, Dema explained that, for him, 'punk' actually covers a wide range of musical forms, including hardcore, black metal, and punk-reggae. Dema preferred the latter style to deliver his punk message. In pursuit of this, Dema and some friends formed a band. 
'What?' I said, 'Who?' His answer surprised me. They were the Sufis, he said. The Sufis dressed and lived unlike ordinary people. Like punks, they were not interested in materiality. Also, there have been many cases of persecution of Sufis in Islamic history. I asked: "Do you consider yourself to be a Sufi, Dema?" "No," he answered immediately, "I am a punker."

Dema's family background and his views on early Islamic history inform some of the ways in which he understands and articulates his engagement with punk, and vice versa. Thus, he offers a striking example of the complexities that characterize the diversity of Muslim experience in contemporary Aceh. This descendant of the Prophet has rejected 'mainstream' society for several years. In a small city like Banda Aceh, his appearance draws attention. For many people, Dema and his fellow punks look like aliens who come from a place they do not know. As Faisal Ali, a leading Acehnese ulama expressed it: "Tattoos? Piercings? Dyed hair? That's weird for Aceh. We're not ready for that." To this he added: "This is our community, and in this community you are not allowed to act like that." The "West" is commonly blamed for the behaviour of Dema and his friends. Punkers have been accused of being westernized and of seeking to force Western culture on Acehnese society. Dema himself did not really care about this. Having made the decision to reject society, he was prepared for society to reject him in return.

\section{Punks in Aceh}

The history of punk in Aceh, and in Indonesia more broadly, remains to be written. The first punk community began to become publicly visible in Banda Aceh around 1998. According to Dema and his friend Dedi Besi, punks emerged in the context of rising political tensions between Acehnese separatists and the central government in Jakarta following the fall of the New Order regime. At that time, punk activists worked hand in hand with student activists to promote the possibility of a referendum about Aceh's independence from Indonesia. ${ }^{8}$ Many of the graphics, posters, murals and pamphlets in support of the referendum movement were created by punkers. While many of these punks were local university students, they distinguished themselves from other campus

7 See Patrick Win, "Anarchy in Aceh: Criminalizing Punk Rock under Islamic Law," http://www .globalpost.com/dispatch/news/regions/asia-pacific/indonesia/120202/aceh-punk-rock -islamic-law-shariah (Accessed 12 June 2014).

8 Interview with Dema, Dedi Besi and Jal Kayu, 6 January 2012, Banda Aceh. 
activists by their punk attire worn during a series of public demonstrations. They formed several rock bands, playing gigs at the Banda Aceh Cultural Park (Taman Budaya Banda Aceh) as a means of voicing their protest to the ongoing political violence in Aceh. ${ }^{9}$

Despite these efforts, attempts to find a peaceful solution for the political crisis in Aceh proved unsuccessful during the early years of the 21st century. The situation changed dramatically, however, as a result of the devastating tsunami of December 2004. Like nearly all segments of society, Banda Aceh's punk community suffered great human losses. It took years for the community to recover. One punker told me that the re-emergence of the punk community in Banda Aceh started on 9 September 2009. His choice for this date to anchor his narrative-evoking popular punk fascination with the emblematic numbers of 999 and its associated 666 - was intentional. ${ }^{10}$ It appears, however, that punks had started to become visible again in post-tsunami Aceh even before this symbolic date. ${ }^{11}$

Dema claims to have been a punker since 1998. Looking back, he stated that the punk community of Banda Aceh would never have grown to its present size were it not for the event of the tsunami and the Helsinki peace agreement. The economic boom in Banda Aceh after the disaster was a significant factor, with reconstruction jobs attracting punks from different parts of Indonesia. In early 2011, the local daily Serambi Indonesia listed several punk groups active in Aceh, including Rantai Hitam (Black Chain), Museum Street Punk, Rock in Love, Damai Boleh Ribut Boleh (Peace Ok Chaos Ok), Netral, Anak Brutal (Brutal Kids), Ello, Tanggoel Rebel (Rebel Dam), Jusuid Guero, Black Green, Breume + Horizontal, and Lem of Gun. ${ }^{2}$ Today, there are hundreds of punks in Banda Aceh, who congregate in a number of well-known spots, including the Dutch colonial cemetery (Kerkhof Peutjoet), the Tsunami museum and the Blang Padang green at the heart of the city.

Dema identifies two different types of punks. The first refers to those who choose to live as homeless 'nomads.' The second group consists of those who have stable addresses, and often have regular jobs, but who don punk gear and

Punks' strong relationship with students and civil society activists was also clearly seen in the event called "Occupy Banda Aceh," a public demonstration in front of the Governor's office on 11 November 2011. For more on this, see "Occupy Banda Aceh," http://www .acehkita.com/berita/hari-ini-aksi-occupy-banda-aceh/ (Accessed 12 June 2014).

10 Interview with Lowbat Boeloek, 20 January 2012, Banda Aceh.

11 For example, on New Year's Eve of 2008, punkers rallied around the city of Banda Aceh even though the MPU had officially banned the celebration of this holiday. 
hang out with other punks from time to time. The first group often considers the second to be 'posers.' In their view, these 'occasional punks' are mostly teenagers imitating a punk-look 'just for fun,' without the motivation to become a 'real' punk, that is, to commit themselves to the ideals of a punk ethic. Although many of his friends were highly critical of the posers, Dema was rather moderate in his view. He believed that the original punk community in Aceh also started as posers, after which some of them went on to become 'true punkers.'

Another striking senior figure within Aceh's diverse punk community is Dedi Satria, or Dedi Besi. Dedi was first attracted to the punk lifestyle and ideology when he was a student at Gajah Mada University (UGM) in Yogyakarta (Central Java). His sobriquet, Dedi Besi ('Iron Dedi') comes from his well-known habit of using scrap metal, especially rusty nails he finds on the streets, as clothing accessories. Dedi, who is often seen carrying around a small guitar, has been involved in a number of traditional music projects with local artists. He is also an occasional lecturer in archaeology at the Faculty of Arts and Humanities (Fakultas Adab) at the State Islamic University at Banda Aceh (UIN Ar-Raniry), an institution that has been central to the design and implementation of Aceh's current Islamic legal system (Feener 2013, 88-90). While this might seem strange to some, as I will show, complex relations to Islamic ideals and institutions characterize the lives of a number of prominent figures in Aceh's punk scene.

Lowbat Boeloek is one of the leaders of an Acehnese punk group called Tanggoel Rebel (Rebel Dam). When I interviewed him, he was finishing his studies in the Economics Faculty of Syiah Kuala University. Lowbat formed a community of punks during the early days of post-tsunami reconstruction. It included 27 members, who, according to Lowbat, shared solidarity, a sense of family, and a spirit of community service. He claimed that the punkers in his group regularly performed the five daily prayers (salat), and that they helped to clean Banda Aceh's streets of rubbish. While conforming to basic religious and civic ideals, Lowbat was highly critical of Aceh's Islamic legal system. In his view, aesthetic taste in hair and clothing styles were a matter of individual choice, not something the state had the right to aggressively intervene in. He emphasized that their choices of dress and deportment were sincere expressions, to be contrasted to the hypocrisy of those who claimed to be 'religious.' Punkers, he argues, ought to resist such hypocrisy.

The public profile of Aceh's punks has evolved considerably over the past decade. As the community grew and became more visible, the state Shari'a apparatus (in cooperation with Satpol PP) started to crack down on them. These anti-punk police actions have attracted considerable attention both 
domestically and abroad (Balowski 2012; Hendrie 2014; Idria 2013; Moore 2012). In Jakarta and Yogyakarta, punks expressed their solidarity with their fellowpunks in Aceh. One group, called Solidarity for Aceh Punk United, rallied in front of the national police headquarters in Jakarta, on 19 December 2011. In Yogyakarta, punks gathered on 22 December to condemn the crackdown. International expressions of support for Aceh's punks took place in Moscow, San Fransisco and London, under the slogan "Punk is not crime." A Seattle-based metal and punk label, Aborted Society, initiated the "Mixtape for Aceh" project on 14 December, a project calling on punk music fans to create cassette and CD compilations of punk music, which were subsequently shipped to punk fans in Aceh early January. "Support Indonesian Punks," a Facebook campaign based in Sweden, called on punks around the world to post pictures of themselves in full punk attire. By 16 December 2011, 4500 people had signed up. ${ }^{13}$

Reactions - mostly online - were also heard locally as human rights groups in Aceh condemned the arrests. Aceh Human Rights Coalition executive director Evi Narti Zain said that the police actions were violent and illegal. Other human rights groups, such as LBH and KontraS Aceh, made similar statements. A particularly forceful response came in the form of an article entitled "Aku Azhari, Aku Seorang Punker: Apa Ada Masalah Besar?" ("I am Azhari and I am a punker: What's the big deal?"), posted on Facebook on 13 February 2011. ${ }^{14}$ Within a few hours, more than 170 comments were posted. The author of the article, the Acehnese Azhari Aiyub, is a well-known figure in the Indonesian literary scene. While he does not regularly wear punk clothes or live on the streets like many other punkers, in his published writing he has expressed strong solidarity with Aceh's punk community. In his article, he identifies as a 'punker' in support of those whose human dignity was injured by the arrests and detentions of those involved with the 'Aceh for the Punk' concert. The main argument of his article, which ranged across a broad spectrum of topics from punk ideology to nihilist philosophy and anarchy, was that the existence of punks signified a powerful reaction to the increasingly pervasive hypocrisy and corruption of contemporary society. ${ }^{15}$

13 James Balowski, "Punks become latest victim of Aceh's abusive Shariah laws," Direct Action 38 (February-April 2012), online at: http://directaction.org.au/issue38/punks_become_ latest_victim_of_acehs_abusive_shariah_laws (Accessed 12 June 2014).

14 http://www.facebook.com/note.php?note_id=10150142263646015 (Accessed 15 July 2011). This article has also been published in Distraction Zine 4 (June 2011).

15 Azhari told me that he had previously sent the article to several local mass media but they all rejected his article despite the fact that none of his submissions had been rejected by those publishers before. Interview with Azhari Aiyub, 16 March 2011, Banda Aceh. 
In sharp contrast to these expressions of solidarity stood the responses of Islamic organizations in Aceh, most of which expressed their support for state officials and their crackdown on the punks. Several Muslim student organizations, including KAMMI, HMI and PII, signed a joined press release declaring their full support for any action to ensure the implementation of Sharica. Teuku Zulkhairi, a leading member of the Rabitah Taliban Aceh and a former President of Banda Aceh's State Islamic University Graduate Students Association, is one of the main figures involved in mobilizing popular support for the government's actions against the punks. ${ }^{16}$ In an article entitled "Menyorot Komunitas Punk Aceh" (Observing the Aceh Punk Communities), Zulkhairi attacked those who defend punkers as "playing around with issues of Human Rights" and called those supporting punk people "whose way of thinking should be questioned."17 The argument that appeals to 'Human Rights' (Hak Asasi Manusia) are subversive and dangerous to public order have a long and tragic history in Aceh. During the conflict, appeals to human rights were made by many Acehnese activists, including members of the Rabitah Taliban, in response to abuses committed by the Indonesian military. In the post-disaster, post-conflict period, however, appeals to Human Rights have come to be increasingly discounted by many Muslim groups in Aceh as symptoms of westernization and even Christianization - and thus as a threat to the implementation of Shari'a.

Teuku Zulkhairi's statements are in accordance with sentiments common among many ulama, who support the project of state Sharia in Aceh. At the same time, they resonate with a set of concerns that have a broader basis in contemporary Acehnese society. Religious authorities and ordinary Acehnese commonly refer to the 2004 tsunami in Islamic terms, perceiving it as a critical moment in the moral development of the Acehnese Muslim community (see for example Idria 2010; Samuels, this volume). As Kloos argues in his contribution to this volume, the changes wrought on post-disaster, post-conflict Aceh have been regarded with suspicion as much as they have been welcomed. It is a common view in Aceh that cultural influences from 'outside' are threatening the moral foundations of Acehnese society. From this perspective, it becomes clear why it is feasible, or even plainly logical, for conservative opinion makers to compare the revival of punk to issues like human rights and foreign intervention. In this framework, recent changes - particularly the 'opening up' of Aceh as a result of the tsunami and the peace process - have come to be presented,

\footnotetext{
16 The Rabitah Taliban Aceh or RTA is an organization of students and alumni of traditional Islamic boarding schools (dayah) in Aceh.

17 Harian Aceh, 24 January 2012.
} 
by some, as signs of the detrimental intrusion of Acehnese society by non-local, non-Islamic values. In the following section, I will move beyond the discursive level to examine how 'dealing with punks' has become part of state practices connected to the implementation of Shari'a.

\section{Punks and the Socialization of Shari'a}

Over recent years, the government of Aceh has situated the 'problem' of punks squarely in the context of the implementation of Islamic law. Government officials in Banda Aceh have stressed that they are driven by a desire not to punish the punks, but rather to 're-educate' them. Banda Aceh's former Deputy Mayor, Illiza Sa'duddin Djamal, who led the raid on the 'Aceh for the Punk' concert, characterized punk as a "a new social disease" (penyakit sosial baru). ${ }^{18}$ She told the media that her motivation to take action against the concert was to intervene against a group whose lifestyle contravened Islamic law and local social norms. As she expressed it, "they must be re-educated (kembali dibina) in order to bring them back to the right path of Islam and the Acehnese culture."19 In her view, the social disease of the punks must be cured through processes of education and socialization (pembinaan). In addition, she stressed that she viewed it as her responsibility - both as a government representative and as a mother - to guide those youngsters who had gone astray.

Behind these emotionally and politically charged justifications, there are problems with the government's response to the incident at multiple levels. One set of problems is procedural in nature. Critics of the legal handling of the 'Aceh for the Punk' crackdown have pointed out that the Deputy Mayor was not following standard regulations when the youngsters were arrested, and she subsequently asked security officials to detain and 'educate' (membina) the punks at the police academy in the mountainside town of Saree, where the detainees were under the exclusive authority of the state police. There, as the world saw through the photographs and videos that moved across the global mediascape, the detained punks were beaten, shaved, and jailed without trial.

Another, more important, problem concerns the apparent continuation of New Order practices within the framework of state Shari'a. In mid-December 2011, I visited the detained punks in the boot camps in Saree to see how the

\footnotetext{
18 http://www.globalpost.com/dispatch/news/regions/asia-pacific/indonesia/120202/aceh -punk-rock-islamic-law-shariah (Accessed 12 June 2014).

19 http://www.tempo.co/read/news/2011/12/15/058371825/Anak-anak-Punk-di-Aceh -Ditangkap (Accessed 12 June 2014).
} 
pembinaan process was carried out. I observed that the detainees were forcibly bathed in what was called a 'holy lake' (kolam suci), actually just a stagnant pond on the police barrack grounds, to 'purify' their bodies. After this humiliating 'cleansing' ritual, they were forced to perform a series of militaristic exercises. $^{20}$ The police officer in charge told me that the punks were undergoing pembinaan so that they could learn to physically and morally discipline both their bodies and their souls. When I asked who decided on this program of 'reeducation,' the same officer responded that the government of Banda Aceh had both allocated a budget and dictated the content of the program of 'instructing' the punks according to the standard operational discipline of the police camp. ${ }^{21}$

The Indonesian term for this kind of 're-education' (pembinaan) is derived from an Arabic root with connotations of literal 'edification.' The Indonesian form, however, comprises a prominent element of the jargon popularized by the authoritarian New Order regime, to justify its acts of repression. During the Soeharto era, the term was used euphemistically for indicating diverse acts of violence carried out by the state apparatus against its own citizens. ${ }^{22}$ In Aceh during the conflict, pembinaan was often understood to refer to torture at the hands of the military. Given these associations, it is not surprising that critics of the government's actions against the punks in 2011, raised spectres of past atrocities, thus sparking sharp condemnation.

On more formal grounds, critics highlight the fact that no articles exist in either the provincial laws of Aceh (qanun; including those pertaining to Shari'a) or the national legislation (KUHP) that would justify the state's arrests of the punks, or their treatment while under detention. ${ }^{23}$ The Chair of the National Commission for Child Protection, Arist Merdeka Sirait, sharply condemned the detention without charge, the head shaving, the ritual cleansing and the military-style treatment, arguing that they were a breach of human rights. ${ }^{24}$ Points of procedure, however, are only one - and one might argue only a minor-aspect of the differences of opinion between provincial government

20 Public humiliation in the forms of such mock 'purification' rites has been common in village vigilante enforcement of Shari'a norms in many parts of Aceh. See Feener (2013a, 244-246) and cf. Kloos (2014; this volume); Otto and Otto (this volume).

21 Interview with a police officer at the Satpol Compound in Saree, 21 January 2012.

22 I derive this analysis of language from a conversation with James Siegel in Banda Aceh, December 2012. For a more general discussion of the notion of force in language, and how it was used by the New Order regime, see Siegel 1986.

23 Personal communication with staff members of the LB H Banda Aceh, Hospi Novizal Sabri and Fauzan Febriansyah, 22 January 2012.

24 Balowski, 2012. 
officials and the public supporters of punks in Aceh. For on a larger, conceptual level their respective positions reflect a fundamental disconnect between their views on the legitimacy of the coercive enforcement of normative morality. Moreover, they also reflect dramatically divergent understandings of how outward forms of dress and deportment are seen in relation to interior spiritual and psychological states.

For Aceh's punks, and many of those concerned with their plight, the issue at hand is that of individual liberty and freedom of expression - a position that might be seen as reflecting particularly 'romantic' conceptions of the relationship between a person's inner self and its outward forms of expression. The dynamic of external forms in relation to the interior state of one's soul are, however, viewed differently by many of the architects and agents of Aceh's state Sharica system. For them, visible markers of sartorial style are not only reflective of the state of one's soul. Rather the adoption (or even enforcement) of particular forms of dress and deportment are seen as important means for instilling desired moral values in individuals - as reflected in the conceptions of syiar and sosialisasi that dominate the work of Aceh's Shari'a Agency (DSI; see Feener 2013a, 202-212). Acehnese officials, who view Islamic law as a potential tool for programs of social transformation, aim "to use the new Islamic legal system to bring about sweeping social change in both the regulation of society and the character of individual Muslims to conform to a particular set of modern ideals." 25

In pursuit of this project, institutions of Aceh's Islamic legal system devoted much of their attention to programs for 'socializing' Shari'a laws (sosialisasi). Sosialisasi thus became the rubric under which their work was conceptualized, as the term came to be used in connection with a wide range of activities, from mass-media campaigns and religious sermons to roadside checkpoints and $\mathrm{WH}$ patrols. Common in all these sosialisasi programs was an overriding concern for outward expressions of piety, including 'respect' for Islamic symbols (syiar) and the wearing of 'proper' Muslim dress (Feener 2013a, 197-205). These concerns were often regarded by critics as focused on 'merely' symbolic aspects of Islam, while neglecting what they viewed as more 'substantial' concerns. Such critiques, however, often miss one important aspect animating state Shari'a projects of sosialisasi: the ways in which the designers of the system perceive the connections between outward signs and inward states. Following a model of moral pedagogy well established in Islamic traditions, but ultimately reach-

25 Feener $(2012,286)$. A broader discussion is developed in Michael Feener's recent monograph (Feener 2013a). 
ing back to Aristotle, the architects of Aceh's contemporary Islamic legal system see the enforcement of good habits of deportment as facilitating the eventual inward transformation of individuals. ${ }^{26}$

This ideal formulation of the state Shari'a system, however, was not immune to compromise and contestation, especially since it came to be implemented through the machinery of an inefficient and unprofessional state with a long legacy of corruption, manipulation, and authoritarianism. ${ }^{27}$ The $\mathrm{wH}$, an institution that was conceived to be a major motor of sosialisasi, came to be regarded in some circles as little more than thugs for their heavy-handed treatment of individuals, and as such, as violating public standards of morality (Otto and Otto, this volume). With the increasing openness of public discourse in post-disaster and post-conflict Aceh, critiques of the wH's 'arrogance' and 'hypocrisy' spread beyond coffee house conversations to take a prominent position in popular media discourse (Feener 2013b).

Tensions between the ideal formulations of 'socializing' the Shari'a by using the state apparatus of the legal system to facilitate public moral education and the exigencies of day-to-day practice in a highly contested political arena increasingly impacted the way in which the Islamic legal system actually worked, and the ways in which its work was popularly perceived. One of the major milestones along this twisted path came in 2007, when the wH was removed from the supervision of the State Sharica Agency (DSI) and placed under the authority of the public order police (Satpol PP). This move heightened negative images of the $\mathrm{WH}$ in the minds of many Acehnese, as the Satpol had a long history of association with authoritarian action, and was popularly regarded, in Aceh and throughout Indonesia, as the state's 'destroying force' (pasukangusur). Satpol's uncompromising and threatening public image was one that evoked conceptions of control, rather than moral persuasion. The wH were thereafter clearly seen as a Sharica 'Police force'-with all the negative connotations that such a designation carried for many in post-conflict Aceh.

The move to merge the wH with the Satpol PP was authorized by thenGovernor Irwandi Yusuf. During the conflict, Irwandi had been a representative of the Free Aceh Movement (Gerakan Aceh Merdeka/GAM) and shared the

\footnotetext{
26 R. Michael Feener, personal communication, 16 May 2014.

27 On the internet, videos of the wH's harsh treatment of suspected offenders are numerous. For edited clips of a WH patrol and interviews with detained punks with English commentary and subtitles, see this documentary by Farish Noor and his team: http://www .channelnewsasia.com/tv/tvshows/inside-indonesia/going-it-alone/110430o.html (Accessed 12 June 2014).
} 
former rebel organization's cynicism regarding the implementation of Shari'a. GAM's leadership was (especially before the tsunami and the Helsinki peace agreement), extremely critical of Shari'a and saw it as a tactic on the part of the central government to manipulate the needs of the Acehnese for independence (see Missbach, this volume). During the first half of his term as Governor, Irwandi expressed his opposition to the expansion of the Islamic legal system by curtailing state funding for its institutions and refusing to sign or implement the controversial Islamic Criminal Code (Qanun Jinayat), passed by outgoing members of the provincial legislature in 2009 (Großmann, this volume).

Foreign observers praised Irwandi as a secular and moderate governor who valued pluralism and freedom of expression. It might have been expected, then, that he would have been critical of the persecution of punks and their rights to free public expression. It became clear, however, that he was either unwilling or unable to intervene in any way to mitigate the treatment of those arrested and detained at the 'Aceh for the Punk' concert. Rather, Irwandi increasingly seemed to avoid alienating parties supportive of Sharica, a trend which grew stronger during his (failed) campaign for a second term in 2011. These political reconfigurations significantly contributed to shape the ways in which state officials responded to the 'Aceh for the Punk' concert, and further complicated a complex social landscape characterized by "the emergence of new and contested expectations and activities in the pursuit of Islamic religious and social ideals" (Feener 2013b, 17).

\section{Aceh's Punks: Enemies of the Shari'a or Enemies of the State?}

Punk, at the very basic level, is a subculture best understood as being part youth rebellion, part artistic statement (Sabin 1999). During its heyday, from 1976 to 1979, it was a highly visible element of youth society both in the UK and the Us. It manifested itself primarily in music, expressing a range of attitudes, from an emphasis on negationism (rather than nihilism), a consciousness of class-based politics (with a stress on 'working class credibility'), as well as belief in spontaneity and 'doing it yourself.' Ian Moran described punk as a 'Do-It-Yourself Subculture' (2011). Punk's 'DIY ethic' has implied a range of tactics for subverting mainstream culture. In this sense, it has been compared to other subcultures expressing an 'alternative' aesthetics, including the hippy movement, leading some to see the emergence of punk as a new manifestation of the counterculture of the 1960s (Sabin 1999, 4).

There is, however, considerable diversity within the punk scene and, as Sabin suggests, punk should not be reduced to the 'ideologically sound' prism of the 
1980 and 9os. Instead, the diverse manifestations of punk should be viewed and analysed within their own specific contexts. In Indonesia, punk communities appeared mostly in large cities, such as Jakarta, Bandung, Surabaya, urban Bali, and Yogyakarta. In these places, punks were recognized as a distinct social presence with a particular public image. In the rather different social contexts of smaller cities, however, other dynamics informed the popular perceptions of the punks, particularly in relation to 'deviant' behaviour. In Banda Aceh, people generally knew very little (if anything) about the nature and the history of the punk community. As a result of this, the general public often tended to lump punks together with motorbike clubs and young beggars. During the postdisaster/post-conflict period, these views influenced broader public reactions to the diverse groups that emerged and either identified themselves, or were popularly identified with, 'punk' in this provincial context.

In Aceh (as elsewhere), punks highlight what they see as a sharp distinction between social convention and the free expression of one's 'true self.' The way that punks dress and behave in public are obviously troubling for the authorities in Banda Aceh. Police regularly intervene to break up gatherings of punks in parks and other public places across Banda Aceh. Their sometimes heavy-handed ways of doing so, have significantly furthered tensions with the punks. At the same time, the punks' continued insistence on the public display of their counterculture is a source of deep irritation for many state Sharia officials. As one wH officer in Banda Aceh told me: "Punkers have to respect the culture of Aceh and Islamic Law. If they do not do that, they have to leave Aceh. There is no place in Aceh for those who do not follow Shariaa." ${ }^{28}$ For supporters of the state Shari'a system, public norms of dress and deportment are critical to their project of transforming Acehnese society in line with their understanding of Sharica ideas.

To further complicate the issue, one has to recognize that - contrary to dominant media polemics in Aceh-in reality there is no line dividing 'punks' and 'Muslims.' Dema, Lowbat Boeloek, and other punks I spoke to all maintained that many punks "are still good Muslims." ${ }^{29}$ While acknowledging that there are diverse types of punks in Banda Aceh-including those who commit offenses against Shariaa law, such as gambling and drinking alcohol—they asserted that some of them were diligent in prayer and fasting. Addressing this range of personal religious observance among Aceh's punks, they asked—rhetorically—in what ways this was different from Acehnese society more broadly.

28 Interview with 'Sy' (a pseudonym), 14 April 2012, Banda Aceh.

29 Interview with Dema, 29 December 2011, and Lowbat, 22 January 2012, in Banda Aceh. 
The perception of a double standard leads to frustration among those punks who continue to uphold what they see as 'Islamic' belief and practice, while at the same time being persecuted by state Shari'a officials. In this respect, the plight of at least some of Aceh's punks might be viewed in relation to the broader phenomenon of state action against 'deviant' groups. ${ }^{30}$ According to Dema, Punks must unite and fight against such unjust persecution. ${ }^{31}$ The 'Aceh for the Punk' concert that ended with the arrest and detention of punks, and from which Dema had fled to the Komunitas Tikar Pandan, was itself a major attempt by the punks to push back against their persecution by state officials.

The idea of the 'Aceh for the Punk' concert was conceived and developed during a series of meetings in which Lowbat had brought together many of Aceh's leading punks in search of ways to create a more positive image. The music concert was to be organized as a charity event to raise money for orphans. However, the most important message of this event is shown by the phrase they chose for the concert title, 'Aceh for the Punk.' Lowbat insisted that through this event they wanted to claim Aceh as a safe place for all to live, and for punks in particular. Their argument for the possibility of punks living harmoniously in 'Islamic' Aceh was based on the view, held by Lowbat, Dema and a number of other punks in Aceh, that their way of life is compatible with what they understand to be the ideals of the Shari'a. Islam, in their view, cannot be limited by the narrow understandings of certain state agencies.

Ironically, the 'Aceh for the Punk' concert was part of a broader campaign of public activities through which Aceh's punks sought to demonstrate to their neighbours just how "normal" they were. Other activities of this campaign included their involvement in a broader activist scene, most notably through demonstrations against corruption and political violence. ${ }^{32}$ For example, they joined in a peaceful demonstration in front of the governor's office during the celebration of the Human Rights Day. In addition, Lowbat claimed, punks helped the Banda Aceh government to clean the city by collecting garbage from the city streets and public places, despite the government labelling the punks as "the refuse of the society."

It seems that these efforts were successful, at least to some extent, before the crackdown on the concert. For example, Aceh's leading daily newspaper

30 For more on the campaign against 'deviant' religious teachings by the institutions of state Shari'a in Aceh, see Feener (2013a, 120-126).

31 Interview with Dema, 29 December 2011, Banda Aceh.

32 Acehnese anti-corruption organizations such as GeRAK and MATa have acknowledged the involvement of punks as their regular supporters in public demonstrations against corruption. 
accepted an article by a young writer, Makmur Dimila, titled "Punks are also Human Beings." ${ }^{3}$ Providing information about Muslim punks and their positive activities in many parts of the world, Dimila argued that people cannot judge the morality of punks only by looking at their dress and hair styles. Dimila's arguments echoed those made by Dema, Lowbat, Dedi, and other punks who have attempted to broaden the perspective of their Acehnese neighbours by calling attention to the ways in which punks have established themselves in other parts of Indonesia. Thus, they often pointed to the "Muslim punk" community in Yogyakarta, who are known to dress like punks while, at the same time, being practicing Muslims. In addition to singing on the streets as punks do elsewhere across the country, this group regularly gathers in religious study groups they call "PUNKajian"-playing on the common Indonesian term for religious education (pengajian). ${ }^{34}$

\section{Criminalization of Punk}

Some of the fault lines of tensions between punks and state officials in Aceh can be traced through local media discourses. It was the popular daily newspaper Harian Aceh that appears to have first publicly cast punks in their charged symbolic role of opposition to the Shari'a by publishing an anonymous letter to the editor, entitled 'Punk Ancaman Bagi Syariat Islam' ('Punk is a Threat to the Shari'a'). ${ }^{35}$ The letter warned readers about the presence of an "un-Islamic culture" in Banda Aceh and the author urgently demanded the local government to take serious action to counter this deviance, in order to defend the implementation of Islamic law. ${ }^{36}$ The media campaign against Aceh's punks was continued in the largest local newspaper, Serambi Indonesia. Its headline of 6 January 2011 highlighted the story of a mother who had lost control of her daughter, after the latter joined a punk community. In her attempts to get her daughter back, she appealed for help from the WH. The story was complemented with a dramatic photo of the mother crying in front of the State Shari'a Agency office. ${ }^{37}$

Such analyses of punks as threats to the social order and the family became a rather common element of media coverage of the clashes between the punks

33 Makmur Dimila, “Punk Juga Manusia," Serambi Indonesia, 19 January 2011.

34 http://punkmuslim.multiply.com/ (Accessed 2 February 2012).

35 Harian Aceh is a popular daily newspaper and owned by Muhammad Nazar, the former lieutenant governor of Aceh (2006-2012).

$36 \quad$ Harian Aceh, 5 December 2010.

37 Serambi Indonesia, 6 January 2011. 
and the police (including the $\mathrm{WH}$ ) during their raids and sweepings. As the issue was propelled to public prominence and the situation escalated, a number of parties attempted to intervene, inviting both police and representatives of punk communities to attend dialogue sessions. A number of such discussions were held in Banda Aceh, and in March 2011, the Law Faculty of Syiah Kuala University organized a public seminar on the issue. There, wH officers, punks, and academics sat together in search of "common understanding." However, physical clashes between the police and punks continued. Just before the start of Ramadan, on 29 July 2011, the wH conducted raids against punks at several locations in Banda Aceh. ${ }^{38}$ During one of these actions, a punker named Rully (aka 'Oyie') was arrested and beaten by the authorities. A journalist from Harian Aceh told me that the beating occurred within sight of the Deputy Mayor of Banda Aceh. ${ }^{39}$

Many critics see the former Deputy Mayor's support of aggressive police campaigns against Banda Aceh's punks as related to her interest in promoting the city's struggling tourism industry. In December 2010, the municipal government had launched the "Visit Banda Aceh 2011" campaign, promoting the city as a centre of "Islamic Tourism" (Banda Aceh Bandar Wisata Islami). ${ }^{40}$ In her attempts to crack down on the punks, the Deputy Mayor was able to draw on a larger base of public support motivated by concerns going beyond the city's 'Islamic' public image, including all those who were sympathetic to the broader project of state Sharica as a means of social and moral reform.

As elsewhere, punks in Aceh present a striking visual profile in public, marked by symbols including leather jackets, accessories, piercings, tattoos, and colourful Mohawk hairdos that serve to distinguish them from the majority of people in society. However, the divide between punks and supporters of the state Sharia system runs far deeper than the specifics of sartorial style. The issue is not only that they look very different, or even unsightly on the urban landscape of this 'Abode of Islam.' Rather, the architects and supporters of the Islamic legal system maintain that the 'correction' of such deviant outward behaviour is a necessary step toward effecting the transformations of individuals according to their understanding of religious ideals. Such views on 'improving' people through coercive measures of conformity with expressed

38 http://harian-aceh.com/2011/o7/28/satpol-pp-dan-wh-keroyok-anak-punk (Accessed $3^{1}$ July 2011).

39 Interview with Junaidi Hanafiah, a Harian Aceh journalist, 2 August 2011 at Banda Aceh.

40 One Acehnese cultural analyst (who prefers to be anonymous) told me that he was absolutely convinced that there is a strong relation between the raid of punks and the Islamic tourism program launched by the government. Interview, 26 February 2012, Banda Aceh. 
public ideals stands in sharp contrast with what might be described as the Punk Ethic of rebellion against established social norms and its sharp critiques against perceived hypocrisy.

The response of the state has been the criminalization of punk. This strategy has served to impose a model of absolute distinction between the categories of 'punk' and 'Islamic.' Despite arguments by punkers such as Dema, Lowbat, and Dedi and their supporters that those two categories are by no means mutually exclusive, public opinion has been dominated by both government rhetoric and mass media discourse on punks as a source of "moral disorder" or "social disease." The crackdown on punks can thus be seen in relation not only to broader debates about human rights and freedom of expression, but also as reflecting particular dynamics of state attempts at limiting the range of 'acceptable' ways of being Muslim in contemporary Aceh. Yet, in the face of these attempts, Aceh's punks have responded by keeping up their efforts of broadening the possibilities of being Muslim and punk at the same time. Despite continuous harassment by WH and Satpol PP officers, in the years after the raid on the 'Aceh for the Punk' concert, punkers have maintained their presence in Banda Aceh's public space. The case of punk youth in Aceh thus demonstrates that state attempts to limit ways of being have not gone uncontested. In the process, punks, as well as other social groups in Aceh, continue to negotiate the limits of the state.

\section{References}

Balowski, James. 2012. "Punks become latest victim of Aceh's abusive Shariah laws." Direct Action 38 (February-April). Available at: http://directaction.org.au/ issue38/punks_become_latest_victim_of_acehs_abusive_shariah_laws.

Feener, R. Michael. 2012. "Social Engineering through Sharīa: Islamic Law and State Directed Da'wa in Contemporary Aceh." Islamic Law and Society 19:275-311.

- 2013a. Sharia and Social Engineering: The Implementation of Islamic Law in Contemporary Aceh, Indonesia. Oxford: Oxford University Press.

. 2013b. "Hand, Heart and Handphone: State Shari'a in the Age of the sms." Contemporary Islam 7(1):15-32.

Grayman, Jesse Hession. 2012. "Humanitarian Encounters in Post-Conflict Aceh, Indonesia." Ph.D diss., Harvard University.

Hendrie, Doug. 2014. Amalga Nations: How Globalization is Good. London: Hardie Grant Books.

Idria, Reza. 2010. "Muslim Theological Perspectives on Natural Disasters: The Case of Indonesian Earthquakes and Tsunami of 2004." MA Thesis, Leiden University. 
- 2013. "Cultural Resistance to Shariatism in Aceh." In Regime Change, Democracy, and Islam: The Case of Indonesia, edited by Kees van Dijk, 180-201. Leiden: Leiden University. available at: http://media.leidenuniv.nl/legacy/irpfinal2013(2).pdf Kloos, David. 2014. "In the Name of Syariah? Vigilante Violence, Territoriality, and Moral Authority in Aceh, Indonesia." Indonesia 98:59-90.

Moore, Rebekah. 2012. "Unwitting Dissidents: The Aceh, Indonesia Punk Case." Paper presented at the AMs/sEM/sm T Conference, New Orleans.

Moran, Ian P. 2011. "Punk: the Do-It-Yourself Subculture." Social Sciences Journal 10(1): $5^{8-65}$.

Sabin, Roger (Ed.). 1999. Punk Rock So What? The Cultural Legacy of Punk. London: Routledge.

Siegel, James. 1986. Solo in the New Order: Language and Hierarchy in an Indonesian City. Princeton: Princeton University Press. 